\title{
Jury Selection and the Death Penalty: Witherspoon in the Lower Courts
}

A common device used to amuse, or at least to occupy, children at birthday parties is a game called "telephone." A child at one end of the table whispers a story to the person sitting next to him; that person whispers the story to his neighbor and so on around the table. The last person to hear the story must recite it aloud. Frequently, what the last person describes bears little or no resemblance to the original story.

While Supreme Court decisions may be far removed from children's stories, Court holdings frequently undergo the same type of mystifying transformation between the time of their initial pronouncement and their application in lower federal and state courts. The lower court developments following the Supreme Court decision in Witherspoon $v$. Illinois ${ }^{1}$ provide a microcosm of the general process.

The Witherspoon case involved an Illinois court procedure which allowed exclusion for cause of any prospective juror who expressed objections to the death penalty. Forty-seven veniremen had been rejected because of their general views on the death penalty, although only five had explicitly stated that "under no circumstances would they vote to impose capital punishment." The Supreme Court concluded that the jury so selected was not impartial in its role of determining punishment within the meaning of the sixth and fourteenth amendments," but rather constituted "a tribunal organized to return a verdict of death."3 The Court therefore voided the death sentence, but did not overturn the conviction.

1391 U.S. 510 (1968).

2 Id. at 514.

8 Id. at 521. Some jurisdictions have distinguished their cases from Witherspoon by arguing that their statutes, unlike that of Illinois, allowed challenges only when the venireman's scruples against capital punishment would have prevented him from reaching a verdict of guilty. Howard v. State, 84 Nev. 599, 602-3, 446 P.2d 163, 165 (1968); Walker v. State, - Nev. -, 455 P.2d 34, 36 (1969); Duisen v. State, 441 S.W.2d 688, 692 (Mo. 1969). Another court avoided Witherspoon by finding that the jurors were dismissed pursuant to a common law authority to dismiss for bias. State v. Pare, 80 N.M. 364, 368, 456 P.2d 197, 201 (1969). Both arguments are unsupported by Witherspoon which does not differentiate along these lines. Further, the Illinois statute involved in Witherspoon, ILL. REV. STAT. ch. 38, $\$ 743$ (1959), had been excluded in the 
For a number of reasons the Witherspoon ruling was ideally suited for clear and consistent implementation by the lower courts. First, despite the retroactive nature of the decision, ${ }^{4}$ the number of cases to which it applies is relatively small. The ruling does not affect cases where jury trial is waived ${ }^{5}$ or where the judge determines the sentence. ${ }^{6}$ Moreover, the declining availability and use of the death penalty narrows the decision's scope. ${ }^{7}$ Thus, while the Witherspoon rule is extremely important in cases already decided, and will continue to remain important as long as any defendant is subject to the death penalty, the courts in applying Witherspoon are operating in a small, well-defined area.

Second, the ruling deals with an issue, the death penalty, for which most of the population no longer has much sympathy. ${ }^{8}$ As a result, the popular pressures the courts may have felt in implementing highly controversial Supreme Court decisions, like the Miranda rul-

general revision of the Criminal Code which became effective on January 1, 1964. In People v. Hobbs, 35 I1l. 2d 263, 220 N.E.2d 469 (1966), the Illinois Supreme Court upheld the government's challenge of "scrupled" jurors for cause under the new statute, ILt. REV. STAT. ch. 38, \& 115-4(d) (1965), which did not specifically allow such a challenge, and also embraced the "overwhelming weight of authority" which favored such a result even in the absence of statutory authority. People v. Hobbs, 35 III. 2d 263, 274, 220 N.E.2d 469, 475 (1966). Thus, while the Court in Witherspoon was dealing with a case arising under the older statute, it recognized that challenge for "scruples" was part of the judicial gloss on the newer statute, and it may even have been considering the legal principles which are generally advanced in allowing such challenges. If Witherspoon was meant to be a consideration of the general principles, then distinctions among various forms of statutes and common law rules should not be decisive in the application of Witherspoon.

4 Witherspoon was given fully retroactive application by the Supreme Court. Id. at 523 n.22.

5 See People v. Aikens, 70 Cal. 2d 369, 377, 450 P.2d 258, 263, 74 Cal. Rptr. 882, 887 (1969).

C 391 U.S. 510, 517-8 (1968).

7 See generally Jones, The Decline and Fall of the Death Penalty in the Englishspeaking World, in THE PeNalty is DeAtr 244 (B. Jones ed. 1968). The number of prisoners executed in the United States has decreased markedly from 1930, when 155 were executed, to 1967, when two were executed. Bureau of Prisons, Dep'T of Justice, National Prisoner Statistics, Executions 1930-1967, Table 1, at 7 (No. 42, June 1968). This decrease reflects the growing disenchantment of the public with the death penalty. See Witherspoon v. Illinois, 391 U.S. 510, $520 \mathrm{n.16}$ (1968), and a Louis Harris survey which showed $47 \%$ opposed to the death penalty and $38 \%$ in favor. Washington Post, July $3,1966, \S \mathrm{E}$, at 3 . The trend is reflected in the growing number of states which have abolished or restricted the death penalty. See, e.g., statutes cited at 391 U.S. 527 n.7. See also H. Zeisel, Some Data on Juror Atrmudes Towards Capital, Punishment 5-24 (1968) for various statistics, including Gallup poll results, concerning public opinion and the death penalty.

8 See note 7 supra. 
ings on police procedure ${ }^{9}$ or the elimination of prayers or Bible reading from public schools, ${ }^{10}$ do not exist here.

Finally, implementation of the Witherspoon rule does not depend on the actions of non-judicial agencies. Whereas the day-to-day administration of the Miranda rule depended in large measure on the cooperation of the police, the Witherspoon decision operates in an area, the voir dire examination, which is completely subject to judicial control. One would expect the Supreme Court to have more influence and control in dealing with judicial bodies than with nonjudicial agencies.

However, despite all the factors favoring consistent application of Witherspoon, the decision has been often misapplied and occasionally ignored. The major part of this comment will present and analyze the conflicting interpretations the lower courts have given the Witherspoon decision. The comment will then briefly examine evidence relating to a question that was left open in Witherspoon-whether the exclusion of capital punishment objectors biases a jury in its role of determining guilt.

\section{The Appropriate Standard}

The Supreme Court established a "general objections test" for exclusion of a venireman because of his position on the issue of capital punishment:

Specifically, we hold that a sentence of death cannot be carried out if the jury that imposed or recommended it was chosen by excluding veniremen for cause simply because they voiced general objections to the death penalty or expressed conscientious or religious scruples against its infliction. ....11

From this general standard the Court carved out a "two-prong exception":

We repeat, however, that nothing we say today bears upon the power of a State to execute a defendant sentenced to death by a jury from which the only veniremen who were in fact excluded for cause were those who made unmistak-

9 Miranda v. Arizona, 384 U.S. 436 (1966). Some of the problems in the implementation of Miranda are discussed in Comment, Waiver of Rights in Police Interrogations: Miranda in the Lower Courts, 36 U. CHI. L. REv. 413 (1969).

10 E.g., Engel v. Vitale, 370 U.S. 421 (1962), and the cases which it spawned.

11 Witherspoon v. Illinois, 391 U.S. 510, 521-2 (1968). 
ably clear (1) that they would automatically vote against the imposition of capital punishment without regard to any evidence that might be developed at the time of the case before them or, (2) that their attitude toward the death penalty would prevent them from making an impartial decision as to defendant's guilt. ${ }^{12}$

The general objections test and the two-prong exception should be read together as the "joint standard" of Witherspoon, the thrust of which is to provide a jury impartial in fact. A good faith effort by the court to provide such a jury is insufficient; exclusion for cause is permitted only where the juror's beliefs are made unmistakably clear, and where those beliefs would either compel the juror automatically to vote against the imposition of capital punishment or prevent him from making an impartial determination of guilt.

The need for a clear and unmistakable statement expressing inability to vote for the death penalty was reaffirmed by the Court in Boulden v. Holman. ${ }^{13} \mathrm{Mr}$. Justice Stewart, writing for the Court, stated that on the basis of the record, it appeared that jurors who had expressed merely a "fixed opinion" against capital punishment or did not "believe in" capital punishment had been improperly dismissed:

Unless a venireman states unambiguously that he would automatically vote against the imposition of capital punishment no matter what the trial might reveal, it simply cannot be assumed that that is his position. ${ }^{14}$

Determining that the voir dire testimony before it did not provide sufficient information to allow categorization of the degree of opposition to the death penalty, the Court remanded the case to the district court, apparently for further scrutiny of the record. ${ }^{15}$

The Court's standard can perhaps be best illustrated by reference to a rough classification of the spectrum of opinions which reflect conscientious or religious scruples against the death penalty:

12 Id. at $522 \mathrm{n} .21$. The second, or impartiality prong of the test is merely a restatement of the general law which allows a juror who is not impartial to be challenged for cause, and it will not be discussed.

13394 U.S. 478 (1969). Although the petitioner did not make the Witherspoon argument in the lower courts or in his petition for certiorari, he raised it in his brief and oral argument.

14 Id. at 482, quoting Witherspoon v. Illinois, 391 U.S. 510,516 n.9 (1968).

15 "A further hearing directed to the issue might conceivably modify in some fashion the conclusion so strongly suggested by the record now before us." $I d$. at 484 . The Court's most recent statement of the Witherspoon test is Maxwell v. Bishop, $90 \mathrm{~S}$. Ct. 1578 (1970), in which the Court restates its holding in Boulden v. Holman. 
1. If I were a juror on a murder case, I would vote for the death penalty only very reluctantly, if there were no mitigating circumstances.

2. If $I$ were a juror on a murder case, $I$ would vote for the death penalty only if it were a horrible murder and a most terrible murderer.

3. If I were a juror on a murder case, I would never under any circumstances vote for the death penalty, no matter how horrible the crime. ${ }^{16}$

All three jurors may be said to hold "conscientious or religious scruples" against the infliction of the death penalty. Jurors shown to have such scruples, without more, are protected by the Witherspoon holding. But the last juror, who would automatically vote against the death penalty, could be challenged under the two-prong exception.

\section{Applying the Standard}

The federal court decisions interpreting Witherspoon have consistently applied the joint standard announced by the Supreme Court and have insisted on an unambiguous showing that an excluded juror would automatically have voted against the death penalty. In Spencer $v$. Beto, 17 the Court of Appeals for the Fifth Circuit, reversing the death sentence handed down by a Texas district court, quoted both parts of the joint standard. ${ }^{18}$ While conceding that the dismissed veniremen may have had "very strong scruples"10 against the death penalty, the court of appeals held that this degree of opposition to the death penalty alone was not sufficient to sustain the dismissal of the jurors in question for cause. ${ }^{20}$ The same tests were applied in two other cases reviewed by the Fifth Circuit. ${ }^{21}$

The Ninth Gircuit, in Sims v. Eyman, ${ }^{22}$ concluded, after examin-

16 H. Zeisel, Some Data on Juror Attitudes Towards Capital Punishment 8 (1968).

17398 F.2d 500 (5th Cir. 1968).

$18 \mathrm{Id}$. at 502 .

$10 \mathrm{Id}$. at 502 n.s.

$20 \mathrm{Id}$.

21 In Williams v. Dutton, 400 F.2d 797 (5th Cir. 1968), 33 veniremen were excluded when they answered "yes" to the question: "Are you conscientiously opposed to capital punishment?" Id. at 805 n.25. The court stated that exclusion of these veniremen for ". . merely assert[ing] conscientious scruples against capital punishment" did not comport with the Witherspoon standard. Id. at 805 . In Irving v. Breazeale, 400 F.2d 281 (5th Cir. 1968), the record did not contain the jury selection proceedings. The case was remanded to the United States District Court for the Southern District of Missis. sippi with instructions to enter orders appropriate to allow the state court to determine whether the principles of the Witherspoon decision were violated. Id. at 236.

22405 F.2d 489 (9th Cir. 1969). 
ing the record, that the requirements of the two-prong exception had been sufficiently satisfied to justify exclusion for cause of four jurors who stated that they could not vote for the death penalty "regardless of the circumstances" or "regardless of what the facts of the case are"23 and one juror who stated that because of his attitude toward the death penalty he "could not sit fairly and impartially." 24 The Ninth Circuit again construed the two-prong exception in the dicta of Sims v. United States, ${ }^{25}$ which was remanded for a new trial on a different issue. Noting that the Witherspoon issue might arise on remand, the court suggested that a prosecutor could ask "whether a juror under no circumstances would consider bringing in a death penalty verdict." ${ }^{26}$ A positive response to this question would be sufficient to establish that a juror could never impose the death penalty, and would justify exclusion for cause. ${ }^{27}$

In Segura $v$. Patterson, ${ }^{28}$ the Tenth Circuit upheld the death sentence of a man convicted of the first degree murder of his son in Colorado. The court interpreted Witherspoon as forbidding the exclusion of any juror because of his views about the death penalty unless he is "unwilling even to consider all of the penalties provided by state law" and "irrevocably committed to vote against the death penalty regardless of the facts of any particular case." 29 The court affirmed the sentence after finding that the veniremen's answers fulfilled the Witherspoon requirements. ${ }^{30}$

Many states have followed the lead of the federal courts in applying the proper standard enunciated in Witherspoon..$^{31}$ For example,

23 Id. at 447.

24 Id.

25405 F.2d 1381 (9th Cir. 1968).

$26 \mathrm{Id}$. at $1384 \mathrm{n} .5$.

27 The Sims court also noted that the defendant should be allowed to ask the reverse question, "whether under all circumstances a juror feels compelled to return a death penalty verdict when he finds a defendant guilty of first degree murder." $I d$.

28402 F.2d 249 (10th Cir. 1968).

$29 \mathrm{Id}$. at 251.

30 Id. at 252. The Tenth Circuit affirmed the death sentence handed down by another Colorado court in Bell v. Patterson, 402 F.2d 394 (10th Cir. 1968). There, it cited its interpretation of Witherspoon in Segura approvingly, and applied that standard. Id. at 397. For a discussion of the court's interpretation of the effect of an error by the trial court in the application of the appropriate standard see text at notes 102-7 infra. Similarly, the federal district courts generally apply the combined test. In Woodward v. Maxwell, 303 F. Supp. 690 (S.D. Ohio 1969), the court applied the two-prong and general objections test to reverse a death sentence where the testimony of one dismissed venireman was not clear and another would have voted for the death penalty "in the proper case." Id. at 694-5.

31 California: In re Anderson, 69 Cal. 2d 613, 617-9, 447 P.2d 117, 120-1, 73 Cal. Rptr. 21, 24-25 (1968); Florida: Wilson v. State, 225 So. 2d 321, 326-7 (Fla. 1969); Georgia: 
the California Supreme Court has applied the joint standard consistently, emphasizing that it must be "unmistakably clear" that one of the two criteria of the two-prong exception has been satisfied in order for exclusion to be justified. ${ }^{32}$ Chief Justice Traynor, ordering a new penalty trial for the appellant in People $v$. Chacon, ${ }^{33}$ based his decision on the grounds that several jurors were excluded before they had made it "unmistakably clear" that they would "automatically" refuse to vote for imposition of the death penalty. ${ }^{34}$ In People v. Risenhoover, ${ }^{35}$ the California Supreme Court again indicated its desire to eliminate ambiguity by reversing a death penalty because a venireman was excused on the basis of "partial answers" which fell short of demonstrating unmistakable clarity as to his position. ${ }^{36}$

While the federal courts and many state courts have given a reasonably literal interpretation to the Court's language, some courts have departed from the strict wording of the decision and, in the process, have modified and even ignored the apparent intention of the Supreme Court. The remainder of this section will consider the four main ways in which some lower courts have narrowed the protection the Witherspoon standards provide the defendant.

\section{A. The Fair Atmosphere Test}

The Illinois Supreme Court, while recognizing the general objections test and the two-prong exception, has never applied them. It

Miller v. State, 224 Ga. 627, 633-6, 163 S.E.2d 730, 734-6 (1968); Massey v. Smith, 224 Ga. 721, 164 S.E.2d 786 (1968); Whisman v. State, 224 Ga. 793, 164 S.E.2d 719 (1968). A few Georgia decisions were based solely on the general objections test. Dixon v. State, 224 Ga. 636, 163 S.E.2d 737 (1968); Arkwright v. Smith, 224 Ga. 764, 164 S.E.2d 796 (1968); Kentucky: Jaggers v. Commonwealth, 439 S.W.2d 580, 585 (Ky. Ct. App. 1968); Louisiana: State v. Turner, 253 La. 763, 768, 220 So. 2d 67, 68 (1969); State v. Hudson, 253 La. 992, 1020-2, 221 So. 2d 484, 494-5 (1969); Maryland: Veney v. State, $251 \mathrm{Md}$. 182, 187-90, 246 A.2d 568, 571-3 (1968); Mississippi: Armstrong v. State, 214 So. 2d 589, 593 (Miss. 1968); New Jersey: State v. Mathis, 52 N.J. 238, 245 A.2d 20 (1968) (Weintraub, C.J.); North Carolina: State v. Spence, 274 N.C. 536, 164 S.E.2d 593 (1968); Ohio: State v. Pruett, 18 Ohio St. 2d 167, 248 N.E.2d 605 (1969); Washington: State v. Aiken, 75 Wash. 2d 435, 452 P.2d 232 (1969); State v. Smith, 74 Wash. 2d 744, 779-82, 446 P.2d 571, 592-4 (1969).

32 E.g., In re Anderson, 69 Cal. 2d 613, 617-9, 447 P.2d 117, 120-1, 73 Cal. Rptr. 21, $24-25$ (1968).

3369 Cal. 2d 765, 447 P.2d 106, 73 Cal. Rptr. 10 (1968).

34 Id. at 772,447 P.2d at 110,73 Cal. Rptr. at 14 .

3570 Cal. 2d 39, 447 P.2d 925, 73 Cal. Rptr. 533 (1968).

30 Id. at 55-56, 447 P.2d at 936, 73 Cal. Rptr. at 544. Cf. People v. Durham, 70 Cal. 2d 171, 198, 449 P.2d 198, 216, 74 Cal. Rptr. 262, 280 (1969). See also People v. Goodridge, 70 Cal. 2d 824, 839-41, 452 P.2d 637, 646-7, 76 Cal. Rptr. 421, 430-1 (1969); People v. Fain, 70 Cal. 2d 588, 601-2, 451 P.2d 65, 72-73, 73 Cal. Rptr. 633, 640-1 (1969); People v. Bradford, 70 Cal. 2d 333, 345-7, 450 P.2d 46, 52-53, 74 Cal. Rptr. 726, 732-3 (1969). 
applies instead a kind of "fair atmosphere" test. ${ }^{37}$ In People v. Speck,38 the first Illinois death sentence after Witherspoon, the Illinois Supreme Court accurately summarized the general objections test, ${ }^{30}$ and concluded that, while most of the veniremen were questioned exhaustively, not all were specifically asked whether they could never vote for the death sentence. ${ }^{40}$ Fifty jurors were excused "because they stated that they had conscientious scruples concerning the death penalty without stating that they would never impose or consider imposing it."41 After Witherspoon, such a finding would seem to require reversal. ${ }^{42}$ The Illinois court, however, examined "the atmosphere of the proceeding," 43 particularly the voir dire, and affirmed Speck's death sentence on the grounds that

the tone of the proceedings here indicate a sincere desire on the part of the prosecutor and the court (although perhaps not shared by the defense), to determine the jurors' qualifications according to the standard later held acceptable in Witherspoon.44

Explicitly rejecting the Supreme Court's requirement of an "unambiguous statement" by the venireman that he would automatically vote against the penalty, the Speck court found that

when the questions and answers are considered in the context of the entire voir dire examination, in which the prospective jurors were informed of the fact that the defendant was on trial for 8 separate crimes of murder, and in which they were advised that the State intended to ask that the death penalty be inflicted, an answer stating that the juror had scruples against inflicting the death penalty was equiv-

37 The Washington Supreme Court also has emphasized the "atmosphere" of the courtroom. Unlike Illinois, however, it uses this atmosphere as a background against which the voir dire is evaluated. State v. Aiken, 75 Wash. 2d 435, 452 P.2d 232 (1969); State v. Adams, - Wash. 2d -, 458 P.2d 558, 575-6 (1969). Kentucky has cited the "fair atmosphere" test approvingly in dicta. Jaggers v. Commonwealth, 439 S.W.2d 580, 585 (Ky. Ct. App. 1968).

3841 Ill. 2d 177, 242 N.E.2d 208 (1968).

39 It stated that the Supreme Court "held that exclusion of jurors simply on the ground that they had scruples against capital punishment, without further inquiry to determine whether the juror could vote to inflict a death sentence, deprives a defendant of his right to a trial by a fair and impartial jury." Id. at 208, 242 N.E.2d at 225.

$40 I d$. at 211,242 N.E.2d at 226.

41 Id. at 213,242 N.E.2d at 227.

42 See text at notes $35-36$.

4341 III. 2 d at 211,242 N.E.2d at 226.

44 Id. at 209, 242 N.E.2d at 225. 
alent to stating that he would not consider its imposition in the case which was before them.45

The court held that Speck's constitutional rights were not violated.48

In two more recent cases, the Supreme Court of Illinois has extended its "fair atmosphere" approach to deemphasize the significance of the voir dire examination. In People v. Mallet, ${ }^{47}$ the court quoted extensively from Speck in upholding a death sentence where 23 out of 87 prospective jurors were excluded for cause because of their attitudes toward the death penalty. The court at no point looked at the individual questioning of any venireman. Instead it sought to establish the "fair atmosphere" of the trial by noting that there was no examination of veniremen "to see how many could be disqualified on the statutory basis alone . . . ;"48 that the trial court required individual examination of jurors and frequent explanation of the three possible verdicts; and that the defendant was allowed to "constantly remind" 49 the veniremen that they should sign the death sentence only in a proper case. ${ }^{50}$

In a 1969 case, People v. Moore, ${ }^{51}$ the Illinois court followed the same reasoning and again refused to reverse a death penalty. Twelve veniremen were dismissed for cause after they replied affirmatively to the question: "Do you have any religious or conscientious scruples against the infliction of the death penalty in the proper case?" 62

$45 \mathrm{Id}$. at 212, 242 N.E.2d at 227 (emphasis added). The court seems to be saying at the same time that the two-prong test does not apply, and that it is met anyway.

We are aware that in Witherspoon the court stated that unless a venireman states unambiguously that he would automatically vote against the imposition of capital punishment, no matter what the trial might reveal, it cannot be assumed that it is his position. We are of the opinion that the situation here is so different from that in Witherspoon that the comment of the Supreme Court is not binding upon us. Witherspoon requires vacation of a death sentence only where jurors are excused because "without more" they say that they are opposed to capital punishment. (Bumper v. N. Carolina, 391 U.S. $543 . .$. ) Here there was much more than a bald statement of opposition and we do not regard our interpretation of the jurors' responses as an assumption, but a well-founded conclusion based upon the record.

Id. at 212-3, 242 N.E. at 227.

40 The Speck court also relied on the fact that the prosecution had sufficient peremptory challenges at the end of voir dire to exclude all the jurors in controversy. Id. at 213-4, 242 N.E.2d at 227-8. See text at notes 105-9 infra.

47244 N.E.2d 129 (1969). The decision has subsequently been vacated although it is not clear on what grounds. See People v. Moore, 42 IIl. 2d 73, 84, 246 N.E.2d 299 (1969). $48 \mathrm{Id}$. at 135.

$40 \mathrm{Id}$.

50 The court also noted that the defendant did not challenge a selected juror for cause and both sides had "ample" peremptory challenges left at the end of voir dire. See discussion in text at notes 105-9 infra.

5142 Ill. 2d 73, 246 N.E.2d 299 (1969).

52 Id. at 82,246 N.E.2d at $304-5$. 
It appears that this question was all that was asked. ${ }^{63}$ The court stated that Witherspoon was distinguishable because in that case the trial court immediately removed anyone who expressed any doubts at all about capital punishment. ${ }^{54}$ The court then quoted a venireman to show that the court made an effort to select a fair jury ${ }^{55}$ and quoted much of Speck to show that the real test is whether, considering the tone and conduct of the trial, ${ }^{56}$ the defendant received a fair trial.

The fair atmosphere test disregards both the language and intent of Witherspoon. ${ }^{57}$ The Illinois Supreme Court has ignored the twoprong test, holding it "not binding" because, in the court's terms, the circumstances in Speck were different from those in Witherspoon. ${ }^{58}$ But the contention that the facts were so different in Speck that Witherspoon is inapplicable cannot be supported. In both cases a large number of jurors were dismissed after expressing simply a general objection to the death penalty. ${ }^{59}$ In both cases there was no attempt to ascertain the content of their objections. Finally, both cases were tried under exactly the same state procedure.

Since the jurors in Speck, Mallett, and Moore were shown to have only general, not specific objections, a straightforward application of the general objections test would have required reversal in all three cases. The Illinois court in all three cases implied that there was "more" than a general objection to the death penalty in the record, ${ }^{60}$ but it looked to the attitude of the trial court as evidence of this additional specificity. As mentioned previously, Witherspoon requires a jury impartial in fact; the court's good faith effort is irrelevant." The only "more" acceptable under Witherspoon is further voir dire testimony making it "unmistakably clear" exactly what the venireman's position on the death penalty is. While what is considered unmistakably clear may vary with the circumstances, such a

53 The court continued: "twelve jurors positively asserted that they had such scruples and were excused for cause without action by the State or objection by the defendant." Id.

54 Id.

55 Id. at $82-83,246$ N.E.2d at 305.

56 Id. at 83-84, 246 N.E.2d at 305-6. The court also noted that the State had sufficient peremptory challenges to have eliminated those prospective jurors eligible to serve under Witherspoon. Id. at 84, 246 N.E.2d at 306. See text at notes 105-9 infra.

57 Illinois statutory law has been amended to restrict further the effect of Witherspoon. Any case in which a sentence imposed or recommended by a jury is vacated is remanded to the trial court for sentencing. ILL. REv. Srar. ch. 38, \& 1-7(0) (1969).

58 People v. Speck, 41 Ill. 2d 177, 209, 242 N.E.2d 208, 225 (1968).

59 More jurors were so dismissed in Speck, about fifty, than in Witherspoon, where about 42 were so dismissed.

60 People v. Speck, 41 Ill. 2d 177, 212, 242 N.E.2d 208, 227 (1968).

61 See text following note 12 supra. 
finding must be made. ${ }^{62}$ Under the Illinois "fair atmosphere" test, jurors may presently be dismissed without such an unambiguous statement.

\section{B. Incorporation of State Law}

New Jersey, Texas, Oklahoma, New Mexico, and Arkansas have applied a different test in Witherspoon situations-in effect, substituting pre-Witherspoon state requirements for the Supreme Court's standard. The New Jersey Supreme Court in State v. Mathis, ${ }^{63}$ after stating the Witherspoon guidelines, ${ }^{64}$ reviewed its cases and decided that "[o]ur cases define cause [for challenge] in terms agreeable to Witherspoon." 65 The court then examined the voir dire to decide if the trial court applied the state guidelines accurately, and held that no jurors had been dismissed in violation of Witherspoon, since the trial court correctly applied "the concept of cause thus settled by our cases."'The court's opinion at no point demonstrated that the New Jersey standards provided equal or greater protection than the federal test of Witherspoon. ${ }^{67}$ Without such a finding the federal, not the state test should have been applied.

The courts of Texas, New Mexico, Arkansas, and Oklahoma have adopted the above analysis. ${ }^{68}$ In Pittman $v$. State, ${ }^{60}$ the Texas Court of Criminal Appeals concluded that Texas statutory and case law "squares with the requirements of Witherspoon"70 and that "[t]he jury in the case at bar was chosen or selected in the traditional Texas manner."71 Applying Texas standards, the court found no error in the exclusion of three prospective jurors who were "less than ideally unambiguous as to whether they would vote against capital punishment regardless of the facts or circumstances in any case."72

62 Boulden v. Holman, 394 U.S. 478, 482 (1969). See text at notes 14-16 supra.

6352 N.J. 238, 245 A.2d 20 (1968).

64 Id. at $242-4,245$ A.2d at 23.

65 Id. at $244,245 \mathrm{~A} .2 \mathrm{~d}$ at 23.

66 Id. at $247,245 \mathrm{~A} .2 \mathrm{~d}$ at 25 (emphasis added).

o7 It is, in fact, questionable whether the voir dire of certain jurors passed the Witherspoon test. Id. at 248-9, 245 A.2d at 26. Cf. State v. Forcella, 52 N.J. 263, 290-2, 245 A.2d 181, 195-6 (1968), for similar analysis.

68 See Pittman v. State, 434 S.W.2d 352 (Tex. Ct. Crim. App. 1968); Koonce v. State, 456 P.2d 549 (Okla. Ct. Crim. App. 1969); of. Duisen v. State, 441 S.W.2d 688 (Mo. 1969); State v. Pace, 80 N.M. 364, 456 P.2d 197 (1969); Davis v. State, 246 Ark. 842, 440 S.W.2d 244 (1969).

60434 S.W.2d 352 (Tex. Ct. Crim. App. 1968).

70 Id. at 356.

71 Id.

72 Id. at 357. 
It has long been the holding of this Court that if it is doubtful whether the juror had conscientious scruples in regard to the infliction of capital punishment, the court's action in sustaining the State's challenge for cause on that ground will be sustained on appeal. ${ }^{73}$

This holding conflicts squarely with the Witherspoon requirement that the juror's disqualification be on "unmistakably clear" grounds. ${ }^{74}$

In Scott $v$. State, the court again applied the law of Texas. ${ }^{75}$ It recognized "that one or more veniremen may have been excused on challenge for cause without a full showing that they would not in any case vote for the death penalty . . . ."76 but affirmed the penalty because the defense did not examine these men further. The court assumed that defense counsel did not want the juror anyway or was satisfied that the Witherspoon test had been met. ${ }^{77}$

Oklahoma followed a similar approach in Koonce $v$. State. ${ }^{78}$ In comparing Oklahoma law to Witherspoon, the court found the two compatible. ${ }^{79}$ The essential question asked by the prosecuting attorney was:

In a case where the law and the evidence warrant, in the proper case, could you without doing violence to your conscience agree to a verdict imposing the death penalty? ${ }^{80}$

Finding that the above question correctly stated the Oklahoma test, ${ }^{81}$ the court upheld the exclusion of 22 jurors who answered "No." While this statement may conform with the requirements of Oklahoma law, it clearly violates Witherspoon. The crucial inquiry is whether the juror could bring in a death sentence at all, not whether he could do so "without doing violence to [his] conscience."82

In State v. Pace, ${ }^{83}$ New Mexico applied its own standards, but related them to those required by Witherspoon. The court maintained that New Mexico practice had always been consistent with the With-

73 Id. (citations omitted).

74 Witherspoon v. Illinois, 391 U.S. 510, 522 n.21 (1968).

75434 S.W.2d 678, 680-1 (Tex. Ct. Crim. App. 1968).

76 Id. at 683.

77 Id. The court added that the state had not exhausted its peremptory challenges. $I d$. See also Whan v. State, 438 S.W.2d 918 (Tex. Ct. Crim. App. 1969), where the same reasoning was used to affirm another death sentence.

78456 P.2d 549 (Okla. Ct. Crim. App. 1969).

$79 \mathrm{Id}$. at 555 .

$80 \mathrm{Id}$.

81 Id.

82 Witherspoon v. Illinois, 391 U.S. $510,515 \mathrm{n} .9$ (1968).

8380 N.M. 364, 456 P.2d 197 (1969). 
erspoon standard, ${ }^{84}$ and then proceeded to affirm defendant's death sentence despite a finding that two jurors had been excluded without a definite determination that they would not subject a man to the death penalty. ${ }^{85}$

The Supreme Court of Arkansas appears, in Davis $v$. State, ${ }^{86}$ not merely to substitute a state for a federal standard, but almost explicitly to reject that federal standard. After quoting its relevant case law, an 1855 decision $^{87}$ clearly unrelated to the Witherspoon standard, the court commented that

[t]o follow appellant's argument to its logical conclusion would create a kind of anarchy in our system of government whereby the minority will always hold a veto over any established public policy. For instance, since the holding in Bloom v. Illinois . . . it would be almost impossible to enforce some provisions of the 1964 Givil Rights Act, if a court were forced to accept jurors whose private opinions are contrary to the policy of the law. For these reasons we find this point without merit. ${ }^{88}$

In these jurisdictions the substitution of the state for the federal standard has resulted in the dismissal of jurors whose attitudes fit into categories one and two of the bias spectrum discussed above. ${ }^{80}$ These are jurors whose exclusion Witherspoon prohibits.

\section{Harmless Error}

Two arguments have arisen in the lower courts which in effect say that even if the mandates of Witherspoon are clearly not followed in the trial court, reversal may not be necessary since there may be no real harm done to the defendant. The first argument centers around the concept of "systematic exclusion" and the second looks to the remaining peremptory challenges of the prosecution.

1. The Systematic Exclusion Argument. The Court's opinion in Witherspoon is ambiguous concerning whether improper jury exclusions may constitute nonreversible error. While some courts find reversible error if the trial court's standard results in the exclusion of any jurors in violation of the Witherspoon test, ${ }^{90}$ some courts have

\footnotetext{
84 Id. at 368,456 P.2d at 201.

$85 \mathrm{Id}$. at $367,456 \mathrm{P} .2 \mathrm{~d}$ at 200.

86246 Ark. 842, 440 S.W.2d 244 (1969).

87 Atkins v. State, 16 Ark. 568 (1855).

88440 S.W.2d at 247.

89 See text at note 15 supra.

80 See, e.g., People v. Fain, 70 Cal. 2d 588, 451 P.2d 65, 73 Cal. Rptr. 633 (1969); People v. Bradford, 70 Cal. 2d 333, 450 P.2d 46, 74 Cal. Rptr. 726 (1969). Cf. People
} 
argued that only the general method of jury selection employed by the trial court must conform to Witherspoon. A mistake resulting in the exclusion of an individual juror will not invalidate the entire jury selection process, since such an error does not amount to the systematic exclusion of jurors which would destroy the possibility of a representative panel required by the sixth amendment.

The Court of Appeals for the Tenth Circuit came very close to making this argument explicitly in Bell v. Patterson.91 Holding that Colorado state law was consistent with the general objections test of Witherspoon, the court stated that the trial court had the correct test in mind. ${ }^{92}$ It noted, however, that "the relevant consideration is whether an examination of the voir dire reveals that the proper test was in fact applied."93 The Bell court found specifically that two jurors excluded for cause would not automatically have voted against the death penalty, but did not stop the inquiry there. ${ }^{94}$ It considered the voir dire as a whole and affirmed the death sentence based on its finding that thirteen jurors were properly dismissed and a number of others were properly included.

It would appear then that the jury did reflect the prevailing mores of society. It remained neutral in that there was not the systematic exclusion of any significant element of the community. ${ }^{95}$

In Marion v. Beto, ${ }^{96}$ a federal district court affirmed a death sentence where at least six jurors were excused from the panel for reasons inconsistent with Witherspoon. ${ }^{97}$ The court's analysis indicated "that there was no pattern or scheme or plan by the court to exclude, systematically or otherwise, all jurors who had such scruples." ${ }^{\text {"gs }}$ In

v. Varnum, 70 Cal. 2d 480, 491-6, 450 P.2d 553, 560-3, 75 Cal. Rptr. 161, 168-71 (1969), where the court went to great pains to determine that one questionable challenge for cause was proper and to affirm the death penalty.

91402 F.2d 394 (10th Cir. 1968).

92 Id. at 398 n.9.

$93 \mathrm{Id}$.

94 Bell v. Patterson, 402 F.2d 394, 398 (10th Gir. 1968).

95 Id. at 399. In Marion v. Beto, 302 F. Supp. 913 (N.D. Tex. 1969), the court stated the proper tests but affirmed the death sentence even though it found that three members of the jury panel were excused "solely because they had conscientious scruples against the death penalty," id. at 920, and at least three others were excused on the basis of answers that "imply strongly, if not expressly," id. at 920, that they would not invoke the death penalty. The court, citing Bell v. Patterson, 402 F.2d 394 (10th Cir. 1969), used a systematic exclusion argument. Id. at 920-1.

96302 F. Supp. 913 (N.D. Tex. 1969).

97 Id. at $919-21$.

88 Id. at 920 . 
State v. Mathis, ${ }^{90}$ and in State v. Adams, ${ }^{100}$ the Supreme Courts of New Jersey and Washington advanced similar systematic exclusion arguments, and in Pittman v. State, ${ }^{101}$ the Texas Court of Criminal Appeals cited the argument but apparently was not prepared to base its holding on it. ${ }^{102}$

While the "systematic exclusion" argument is not clearly contrary to the holding of Witherspoon, it does seem to violate the spirit of the case. Witherspoon attempted to provide significant protection for criminal defendants facing possible death penalties by insuring that the jury would be impartial in determining the proper sentence. The systematic exclusion argument dilutes that protection. The use of a nebulous standard applicable to the jury selection process as a whole, rather than to individual jurors, presents a number of diffculties. Not only is it difficult to determine when exclusions become "systematic," but it also seems possible to find in every case, as the Tenth Circuit did in Bell v. Patterson, ${ }^{103}$ that some jurors were properly included and others properly excluded. In Witherspoon itself, the trial court properly dismissed five of the forty-seven jurors in question. ${ }^{104}$ Notably, no court using this standard has yet found sufficient exclusion to warrant reversal. Thus, the impact of the systematic exclusion argument is to invite the very evil Witherspoon sought to prevent.

2. The Remaining Peremptory Challenges Argument. A criterion widely applied to determine if there was reversible error below is whether the prosecution had peremptory challenges left at the close of the jury selection. The argument is simply that

it is not unreasonable to assume that the remaining challenges would have been used had the trial court ruled against the State on its objection to a specific juror. ${ }^{105}$

A substantial number of jurisdictions follow this view. ${ }^{106}$ In In re Anderson, however, the California Supreme Court rejected this argument, holding that an assumption that the prosecutor would have

\footnotetext{
9852 N.J. 238, 245 A.2d 20 (1968).

100 - Wash. 2d —, 458 P.2d 558 (1969).

101434 S.W.2d 352 (Tex. Ct. Crim. App. 1968).

102 Id. at 357.

103402 F.2d 394, 397 (10th Cir. 1968).

104 Witherspoon v. Illinois, 391 U.S. 510, 514 (1968).

105 State v. Mathis, 52 N.J. 238, 251, 245 A.2d 20, 27 (1968).

100 Texas: Scott v. State, 434 S.W.2d 678, 683 (Tex. Ct. Crim. App. 1968); Illinois: People v. Speck, 41 III. 2d 177, 213-4, 242 N.E.2d 208, 227-8 (1968); Fifth Circuit: Spencer v. Beto, 398 F.2d 500, 502 (5th Cir. 1968) (dictum); Florida: Campbell v. State, 227 So. 2d 873, 876 (Fla. 1969).
} 
used his peremptory challenges to excuse the jurors in question is "conjecture" and that reversal is automatic if the Witherspoon tests have not been met. ${ }^{107}$ The California approach is similar to the doctrine that "there are some constitutional rights so basic that their infraction can never be treated as harmless error. . .."108 In Tumey v. Ohio, ${ }^{109}$ the Supreme Court declared the right of a defendant to a disinterested judge to be such a right. It would seem contrary to the intent of the Court in Witherspoon to hold that the right to an impartial jury is any less basic or more capable of being "harmlessly" infringed than the right to a disinterested judge.

\section{Waiver}

Like the "harmless error" arguments, the doctrine of waiver represents an attempt to confine Witherspoon through the use of a legal theory not directly passed upon by the Court in deciding the case. The New Mexico Supreme Court has intimated that a defendant may waive his Witherspoon rights by failing to question a disputed juror to determine his attitudes. ${ }^{110}$ Similarly, in denying a motion for rehearing the Texas Court of Criminal Appeals argued that

$[w]$ here as here, several of the venire expressed their convictions against the infliction of the death penalty and appellant's counsel, evidently being satisfied with the veniremen's statements or because he did not want the veniremen for some other reason, made no effort to qualify them for service we do not conclude that ii becomes the duty of the court to take other steps toward attempting to qualify the veniremen. Veniremen may still be excused by agreement in this State. . . .111

The court further stated that it would apply the two-prong exception only to veniremen "whom appellant seriously tried to qualify for ser-

107 In re Anderson, 69 Cal. 2d 613, 619-20, 447 P.2d 117, 121-2, 73 Cal. Rptr. 21, 25-26 (1968). Two jurisdictions have noted that the defense had peremptory challenges left, and built a waiver-of-objections argument based on it: Pittman v. State, 434 S.W.2d 352, 357 (Tex. Ct. Crim. App. 1968); State v. Peele, 274 N.C. 106, 113, 161 S.E.2d 568, 573 (1968). This argument would completely eliminate the protections provided by Witherspoon. Once prospective jurors with scruples against the death penalty are eliminated from the selection process, it is completely useless for defense counsel to challenge a juror peremptorily because of his opinion about the death penalty. The method of selection itself insures that the challenged juror's replacement will not have the feelings against the death penalty desired by the defense.

108 Chapman v. United States, 386 U.S. 18, 23 (1967).

109273 U.S. 510 (1927).

110 State v. Pare, 80 N.M. 364, 367, 456 P.2d 197, 200 (1969).

111 Pittman v. State, 434 S.W.2d 352, 362 (Tex. Ct. Crim. App. 1968). 
vice. . . ."112 It found no such intent where the defendant did not request further interrogation.113 Thus, the court has shifted the burden of proof from the prosecutor, the party making the motion to dismiss a juror for cause, to the defendant. Witherspoon does not support such a shift.

\section{Reversal of Guilt Determination}

At present the application of Witherspoon to guilt determinations is uncertain. While the Court in Witherspoon refused to decide whether the exclusion of capital punishment objectors biases a jury in the determination of guilt, it clearly left the door open for later reconsideration of the issue.

The data adduced by the petitioner, however, are too tentative and fragmentary to establish that jurors not opposed to the death penalty tend to favor the prosecution in the determination of guilt. We simply cannot conclude, either on the basis of the record now before us or as a matter of judicial notice, that the exclusion of jurors opposed to capital punishment results in an unrepresentative jury on the issue of guilt or substantially increases the risk of conviction. In light of the presently available information, we are not prepared to announce a per se constitutional rule requiring the reversal of every conviction returned by a jury selected as this one was. ${ }^{114}$

One of the studies relied on by the petitioner was a preliminary unpublished one page summary of a study by Professor Hans Zeisel based on interviews with 1,248 jurors in New York and Chicago. The study has since been completed.115 To eliminate the extraneous influence of the weight of the evidence in the individual case the jurors were grouped according to the split of the vote on the first ballot (i.e., 11-1, 10-2, and so on). The statistical comparisons were made within these groups. The jurors in those groups which were unanimous, for or against conviction, were eliminated. This left eleven groups and a total sample of 464. Professor Zeisel has concluded:

First, odds are 24 to 1 that the statement is true, that jurors without scruples against the death penalty are more likely to vote Guilty on the first ballot than jurors who have such 
scruples. Secondly, odds are 4 to 1 that the difference in percentage points of Guilty votes will fall somewhere between 4 and 17 percentage points, in the indicated direction. ${ }^{116}$

This study seems to furnish an empirical basis for concluding that jurors not opposed to the death penalty tend to favor the prosecution in determination of guilt. ${ }^{117}$ However, while statistically significant, neither the relationship discerned nor the magnitude of that relationship is overwhelming. When considered together, as they must be here, the degree of certainty with which a conclusion can be stated is diminished. Even if the relationship were absolutely certain, the odds are 4 to 1 that it would only affect one-half to two jurors on the first ballot. Professors Kalven and Zeisel in their study of the American Jury conclude that normally it takes at least two dissenting jurors on the first ballot to affect the outcome. ${ }^{118}$

No court has yet reversed a guilt determination solely on the bases of Witherspoon and the Zeisel study. Before the Witherspoon decision, the Fourth Circuit in Crawford v. Bounds overturned a North Carolina murder conviction because veniremen conscientiously opposed to capital punishment had been excluded from the jury, but its decision has since been vacated and remanded for further consideration in light of Witherspoon.119 Since Witherspoon two courts have, due to idiosyncrasies of their law, remanded for a new trial as to guilt. ${ }^{120}$ A third jurisdiction has reversed a guilt determination citing Witherspoon, but it is not clear from the case or the briefs of the State or defendant why this was done. ${ }^{121}$ While it seems consis-

116 Id. at 32 (author's footnote omitted). The second conclusion means the relationship found will probably affect between $4 \%$ and $17 \%$ of the jury, or roughly $1 / 2$ to 2 jurors of a panel of twelve.

117 Probability theory sometimes enables the computation of the percentage of times a specified chain of events will occur by chance, that is, without identifiable cause. For example, one can state that the probability a true coin will fall heads-up two times in a row is $1 / 2 \times 1 / 2=1 / 4=25 \%$. If a series of events occurs whose probability is small (any ten times heads-up $=1 / 210=1 / 1024=1 / 10$ of $1 \%$ ) the suspicion that the coin was not true will have considerable support. In similar if more complicated fashion, one can compute the probability that a pattern as that shown in the Zeisel study could develop by chance, that is, without there being a systematic relationship between attitude toward capital punishment and propensity to find a defendant guilty of a criminal charge. For more detail on the methodology see Finkelstein, The Application of Statistical Decision Theory to the Jury Discrimination Cases, 80 HARv. L. REv. 338, 338-53 (1966).

118 H. Kalven \& H. Zitsel, The American JuRY 462-3 (1966).

119395 F.2d 297 (4th Cir. 1968), rev'd per curiam, 393 U.S. 76 (1968).

120 Ellison v. State, 432 S.W.2d 955 (Tex. Ct. Crim. App. 1968); State v. Spence, 274 N.C. 536, 164 S.E.2d 593 (1968).

121 State v. Turner, 253 La. 763, 220 So. 2d 67 (1969). The appropriate argument for reversal of the guilt determination was simply not made by the defendant. 
tent with common sense that jurors not opposed to the death penalty would be more likely to vote guilty than those expressing conscientious scruples against capital punishment, it seems unlikely that the Supreme Court will require reversal of guilt determinations in the absence of more conclusive evidence.

\section{Conclusion}

The reasons for the unfaithful implementation of Witherspoon by the lower courts are certainly open to conjecture. Some of the hostility toward the decision may result from its being made retroactive. The courts may simply resent reversing the death sentence of a convicted killer because the jury was chosen in a manner unconstitutional only in retrospect. This objection would be especially true in the case of particularly heinous crimes, such as the Speck murder of seven student nurses, or in situations where the defendant has already been retried and again found guilty.

It is also possible the rejection of Witherspoon is due to the antipathy of the courts toward recent cases such as Miranda extending constitutional guarantees. The lack of finality in judicial handling of serious crimes concerns people. To many it may seem that the continual reopening of factual and legal determinations places an intolerable burden on the judicial system. Finally, some courts may believe simply that Witherspoon was wrong, but may not be as candid in acting upon that theory as the Arkansas Supreme Court. ${ }^{122}$

Whatever the reason, Witherspoon has not been properly implemented. The short history of the decision has been filled with more misinterpretation than is warranted by the ambiguities of the opinion itself. It remains to be seen whether the resulting bad law will remain to distort decisions in less emotional cases in the future and require another Supreme Court decision to repeat what has already been said in Witherspoon.

122 See Davis v. State, 246 Ark. 842, 440 S.W.2d 244 (1969). 